\title{
HUBUNGAN RELIGIUSITAS DAN REGULASI EMOSI SISWA SEKOLAH DASAR
}

\author{
Mikha Angelia ${ }^{1}$, Sri Tiatri ${ }^{2}$, Pamela Hendra Heng ${ }^{3}$ \\ ${ }^{1}$ Program Studi Magister Psikologi, Universitas Tarumanagara, Jakarta \\ Email: mikha.707181001@stu.untar.ac.id \\ ${ }^{2}$ Fakultas Psikologi, Universitas Tarumanagara, Jakarta \\ Email: sri.tiatri@untar.ac.id \\ ${ }^{3}$ Fakultas Psikologi, Universitas Tarumanagara, Jakarta \\ Email: pamelah@fpsi.untar.ac.id
}

\begin{abstract}
Emotional regulation is an individual's ability to regulate emotions. Individual regulate his/her emotion to be able to control his/her life. In practice, the ability of emotional regulation can be influenced by various factors. One of the factors that can influence the process of emotional regulation is the level of religiosity. In this study, researchers aimed to be able to see the relationship of students' religiosity on emotional regelation possessed by students. This study involved 319 elementary school students in SD X. Participants were given a set of assessments to measure the level of religiosity and emotional regulation. Religiosity is measured by using the Dimension Religiosity Scale to measure preoccupation, conviction, emotional involvement, and guidance. To measure emotional regulation, researchers used the Emotion Regulation Questionnaire for Children and Adolescent (ERQ-CA) to measure the level of cognitive reappraisal and expressive suppression possessed by students. Data was analysised using correlation test in SPSS version 23. From the results of the correlation test conducted found that there is a significant relationship between the variables of religiosity and emotional regulation $(r=0.248$, with $p<0.05)$. This shows that if the level of religiosity students have is high, the ability of students to regulate emotions will be better.
\end{abstract}

Keywords: regulation, emotion, religiosity

\begin{abstract}
ABSTRAK
Regulasi emosi adalah suatu kemampuan individu dalam mengatur emosi. Setiap orang melakukan regulasi emosi untuk dapat mengendalikan hidupnya. Dalam praktiknya, kemampuan regulasi emosi dapat dipengaruhi oleh berbagai faktor. Salah satu faktor yang dapat mempengaruhi proses regulasi emosi adalah tingkat religiusitas yang dimiliki individu tersebut. Dalam penelitian ini, peneliti bertujuan mengkaji hubungan antara religiusitas siswa dengan regulasi emosi yang dimiliki oleh siswa. Penelitian ini melibatkan 319 siswa-siswi Sekolah Dasar di sekolah X. Partisipan diberikan satu set asesmen untuk mengukur tingkat religiusitas dan regulasi emosi. Religiusitas diukur dengan menggunakan Dimension Religiousity Scale untuk mengukur preoccupation, conviction, emotional involvement, dan guidance. Untuk mengukur regulasi emosi, peneliti menggunakan Emotion Regulation Questionnaire for Children and Adolescent (ERQ-CA) untuk mengukur tingkat kemampuan cognitive reappraisal dan expressive suppression yang dimiliki oleh siswa. Analisis data menggunakan uji korelasi dengan menggunakan SPSS versi 23. Dari hasil uji korelasi yang dilakukan, didapatkan bahwa ada hubungan yang signifikan antara variabe religiusitas dan regulasi emosi $(r=0,248, \mathrm{p}<0,05)$. Hal ini menunjukkan bahwa makin tinggi tingkat religiusitas yang dimiliki siswa, maka makin tinggi pula kemampuan siswa dalam meregulasi emosi.
\end{abstract}

Kata Kunci: regulasi, emosi, religiusitas

\section{PENDAHULUAN}

\section{Latar Belakang}

Emosi adalah suatu respon yang berkembang secara adaptif, sesuai dengan situasi yang terjadi (Roseman, Demetriou, Wall, Nutt, \& Carhart-Harris, 2017). Emosi dipengaruhi oleh faktor internal dan faktor eksternal. Faktor internal merupakan faktor yang berasal dari dalam diri individu, sedangkan faktor eksternal merupakan faktor yang berasal dari luar diri individu. Faktor eksternal dan internal dapat menciptakan emosi positif ataupun emosi negatif. Menurut Bekerman dan Zembylas (2018), jika individu merespon situasi yang buruk dengan hal positif, 
maka emosi yang didapatkannya ialah emosi yang positif. Sebaliknya, jika seorang individu merespon situasi yang buruk secara negatif, maka emosi yang tercipta pun adalah emosi negatif.

Salah satu penjelasan terhadap emosi terkait dengan keyakinan terhadap emosi (emotion belief) (Ford \& Gross, 2018). Keyakinan terhadap emosi terbagi menjadi dua yaitu, keyakinan terhadap kebaikan (belief about goodness) dan keyakinan dalam mengendalikan (belief about controllability). Belief about goodness adalah keyakinan bahwa suatu emosi dapat menjadi respon jangka pendek dan juga jangka panjang. Sedangkan belief about controllability ialah keyakinan bahwa emosi dapat berkembang secara alami dari dalam diri setiap individu.

Berdasarkan hasil observasi dan personal communication dengan guru di SD X, saat ini, ditemukan banyak fenomena mengenai kurangnya kemampuan mengendalikan emosi di sekolah. Siswa-siswi di sekolah tersebut sering mengucapkan kata-kata yang tidak sopan (contohnya, mengucapkan kata "bego, babi, anjing, shit, damn".

Tindakan bully secara fisik antara lain, satu siswa laki-laki kelas 3 memasukkan plastik ke dalam telinga siswa kelas 1 . Selain itu, beberapa siswa di kelas 4 juga pernah melakukan tindakan yang tidak jujur, yaitu menyontek dan mencuri. Mereka tidak mengakui perbuatan mereka. Menurut mereka, tindakan negatif tersebut dilakukan karena rasa emosi negatif kepada orang tua dan teman. Salah satunya ialah alasan mereka menyontek untuk mengurangi terjadinya perbandingan nilai akademik yang dilakukan orang tua mereka. Selain itu, tindakan mencuri yang dilakukan oleh siswa dikarenakan adanya rasa emosi dan iri terhadap teman yang selalu memiliki alat tulis yang bagus.

Penulis juga menemukan siswa kelas 5 (lima) yang sering terlihat panik. Ia selalu panik jika tidak dapat menyelesaikan tugas, tidak dapat diterima oleh temannya saat bermain, dan meminta tambahan waktu saat mengerjakan ulangan. Lewat kepanikan yang dimilikinya, hal ini dapat membuat suasana kelas menjadi tidak kondusif selama pelajaran berlangsung. Selain itu, penulis juga pernah menemukan satu orang siswa kelas 4 yang melawan guru dan melakukan tindakan bully secara verbal kepada guru. Siswa tersebut pernah menyebut gurunya "aneh" dan menyuarakannya di tengah kelas.

Siswa-siswi sekolah dasar $\mathrm{X}$ mengalami kesulitan dalam mengendalikan emosi. Hal ini menyebabkan banyak permasalahan dan berbagai kasus pun terjadi. Perlu adanya kemampuan untuk dapat mengendalikan emosi negatif yang dimiliki oleh siswa sekolah dasar. Berdasarkan Gross (dalam Pennequin, Questel, Delaville, Delugre, \& Maintenant 2019), regulasi emosi merupakan proses yang memungkinkan individu untuk dapat mengatur emosi alamiah yang dimilikinya. Regulasi emosi dapat membuat individu memahami kapan dan bagaimana mengekspresikan emosi sesuai dengan situasi yang terjadi.

Menurut Gross (2015), ada beberapa hal yang perlu diketahui untuk dapat melakukan proses regulasi emosi. Hal tersebut ialah identification, selection, implementation, dan monitoring. Dalam proses identification, individu mengidentifikasi emosi yang dimilikinya, mendeteksi apakah emosi tersebut dapat diregulasi atau tidak. Dalam proses selection, individu menyeleksi strategi yang dapat dilakukan untuk meregulasi emosi yang dimilikinya. Dalam proses implementation (implementasi), individu mempertimbangkan cara untuk dapat melaksanakan proses regulasi emosinya. Dalam proses monitoring (pengamatan), individu dapat mengamati setiap proses dan hasil dari regulasi emosi yang sudah dilakukannya. 
Berdasarkan Gross (1998), proses regulasi emosi melibatkan situation selection, situation modification, attentional deployment, cognitive change, dan response modulation Situation selection melibatkan pemilihan terhadap situasi yang dapat memungkinkan dirinya untuk dapat menciptakan emosi yang sesuai dengan situasi yang terjadi. Proses situation modification merupakan proses modifikasi dari tindakan secara langsung untuk dapat mengubah dampak emosional. Proses attention deployment merupakan proses memberikan perhatian untuk dapat mempengaruhi respon emosional yang dialami oleh seorang individu. Proses cognitive change merupakan suatu proses perubahan kognitif untuk dapat mengubah penilaian terhadap situasi yang mungkin terjadi karena dampak emosional. Proses response modulation merupakan respon secara langsung yang dipengaruhi oleh perilaku, pengalaman, ataupun emosi yang sedang berkembang.

Menurut Etkin, Egner, dan Kalicsh (2011), terdapat hubungan antara regulasi emosi dan kontrol kognitif. Menurut Hurlock (2013), faktor kesehatan, pola asuh, dan interaksi dengan orang sekitar dapat juga mempengaruhi regulasi emosi seseorang. Selain itu, menurut Vishkin, BigMan, dan Tamir (2014), faktor internalisasi agama atau religiusitas dapat mempengaruhi regulasi emosi individu. Agama memiliki peran dalam memberi dampak terhadap regulasi emosi.

Religiusitas dapat memberikan dampak terhadap pengalaman emosi seseorang. Religiusitas dapat meningkatkan kemampuan regulasi emosi secara intrinsik. Menurut Gross dan John (2003), ada unsur cognitive reappraisal (penafsiran ulang) di dalam faktor religiusitas yang bersifat positif. Menurut Sharp (2010), berdoa merupakan salah satu cara untuk dapat meregulasi emosi negatif. Karena melalui berdoa, individu dapat melakukan penafsiran ulang terhadap situasi yang terjadi, sehingga dapat membuat emosi negatif berkurang. Religiusitas pun dapat mempengaruhi ekspresi emosional, sehingga dapat membantu proses regulasi emosi (Gross \& John, 2003).

Religiusitas pun dapat meningkatkan regulasi emosional dari faktor eksternal. Menurut Diener, Tay, dan Myers (2011), komunitas rohani atau religiusitas dapat membuat individu memiliki dukungan sosial. Hal ini dapat mendukung individu dalam memberikan emosi yang lebih positif terhadap situasi yang sedang dialami.

Berdasarkan uraian di atas, religiusitas diduga berkaitan dengan regulasi emosi. Namun, belum banyak penelitian mengenai kaitan antara religiusitas dan regulasi emosi, khususnya pada siswa Sekolah Dasar. Perkembangan siswa semasa Sekolah Dasar adalah salah satu bagian perkembangan terpenting karena dapat mempengaruhi kehidupan siswa di masa selanjutnya. Dengan demikian, pertanyaan penelitian ini adalah, apakah ada hubungan antara religiusitas dengan regulasi emosi pada siswa Sekolah Dasar?

\section{METODE PENELITIAN}

\section{Partisipan}

Partisipan dalam penelitian ini adalah 319 siswa-siswi kelas 4, 5, 6 sekolah dasar di sekolah X. Sekolah Dasar X adalah sekolah swasta yang pengelolaannya berada di bawah komunitas agama Kristen. Terdapat 101 siswa laki-laki dan 218 siswi perempuan. Pemilihan partisipan dalam penelitian ini dikarenakan tingkat kasus emosi paling banyak terjadi di kelas 4, 5, dan 6 . 


\section{Desain penelitian}

Penelitian ini dilakukan dengan menggunakan metode kuantitatif non-eksperimental dengan pendekatan korelasional. Penelitian ini dibuat untuk melihat hubungan antar variabel yang terdapat dalam penelitian ini.

\section{Prosedur penelitian}

Prosedur penelitian ini terdiri dari beberapa langkah berikut: Tahap pertama, yaitu menentukan topik penelitian, studi literatur terkait dengan topik penelitian, penentuan dan permohonan izin alat ukur dari pihak terkait, melakukan permohonan izin penelitian kepada pihak sekolah, dan menggali informasi terkait kasus emosi yang terjadi di sekolah dengan menggunakan personal communication. Tahap kedua, yaitu melakukan pilot study kepada 31 siswa dari kelas 4, 5, dan 6. Pilot study ini digunakan untuk mengukur pemahaman siswa, reliabilitas, dan validitas dari alat ukur yang digunakan dalam penelitian ini. Tahap ketiga berupa pengambilan data kepada 319 siswa yang berada di kelas 4, 5, dan 6. Tahap keempat ialah analisis hasil penelitian dengan menggunakan SPSS versi 23, penyusunan laporan, dan melakukan uji hipotesis penelitian.

\section{Pengukuran}

Penelitian ini mengukur dua variabel, yaitu religiusitas dan regulasi emosi. Dalam variabel religiusitas, peneliti menggunakan alat ukur Dimension Religiousity Scale yang dirancang oleh Joseph dan DiDuca (2007). Alat ukur tersebut digunakan untuk mengukur tingkat religiusitas siswa dengan 4 dimensi yang berbeda. Ada dimensi preoccupation, conviction, emotional involvement, dan guidance. Terdapat 20 butir soal untuk menguji tingkat religiusitas siswa menggunakan alat ukur ini. Proses penilaian menggunakan 5 poin skala Likert. Poin 1 dengan label "sangat tidak setuju", poin 2 dengan label "tidak setuju", poin 3 dengan label "netral", poin 4 dengan label "setuju", dan poin 5 dengan label "sangat setuju."

Variabel regulasi emosi diukur dengan menggunakan alat ukur Emotion Regulation Questionnaire for Children and Adolescent (ERQ-CA) yang dirancang oleh Gullone dan Taffe (2011), alat ukur ini merupakan hasil adaptasi dari alat ukur regulasi emosi yang didesain oleh Gross dan John (2003). Dengan menggunakan alat ukur ini, ada 2 dimensi dari regulasi emosi yang dapat diukur. Dimensi tersebut ialah cognitive reappraisal dan expressive suppression. Terdapat 6 butir soal dalam dimensi cognitive reappraisal dan 4 butir soal dalam dimensi expressive suppression. Proses penilaian dalam alat ukur ini menggunakan 5 poin skala Likert sangat tidak setuju - tidak setuju - netral - setuju - sangat setuju, yang diskor secara berurutan 1 $2-3-4-5$.

\section{Uji reliabilitas}

Berdasarkan hasil pilot study, ditemukan bahwa tingkat reliabilitas kuesioner religiusitas (yaitu Dimension Religiousity Scale dari Joseph \& DiDuca, 2007) ialah 0,813. Nilai tersebut berada di atas 0,7 (cronbach's alpha), maka dapat dikatakan reliabel. Demikian pula, kuesioner regulasi emosi atau alat ukur emotion Regulation Questionnaire for Children and Adolescent (ERQ-CA) (Gullone \& Taffe, 2012) ditemukan reliabel (cronbach's alpha 0,742). Hasil uji reliabilitas tersebut diperlihatkan dalam tabel 1 berikut ini. 
Tabel 1. Alat Ukur Penelitian

\begin{tabular}{|c|c|c|c|}
\hline Variabel & Nama Alat Ukur & Dimensi & Contoh Butir Soal \\
\hline Religiusitas & $\begin{array}{l}\text { Dimension } \\
\text { Religiousity Scale } \\
\text { (Joseph \& DiDuca, } \\
\text { 2007). } \sqrt{a}=0,813\end{array}$ & $\begin{array}{l}\text { 1. Preoccupation } \\
\text { 2. Conviction } \\
\text { 3. Emotinal } \\
\text { Involvement } \\
\text { 4. Guidance }\end{array}$ & $\begin{array}{l}\text { Saya berdoa untuk } \\
\text { meminta bimbingan } \\
\text { Tuhan. }\end{array}$ \\
\hline Regulasi Emosi & $\begin{array}{l}\text { Emotion Regulation } \\
\text { Questionnaire for } \\
\text { Children and } \\
\text { Adolescent (ERQ- } \\
\begin{array}{l}\text { CA) (Gullone \& } \\
\text { Taffe, 2012). } \text { la }^{=} \\
0,742\end{array}\end{array}$ & 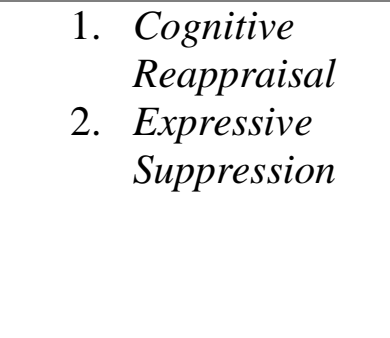 & $\begin{array}{l}\text { Saat saya merasa } \\
\text { sedih, marah atau } \\
\text { kuatir, saya } \\
\text { mengubah cara } \\
\text { berpikir saya } \\
\text { terhadap situasi } \\
\text { tersebut. }\end{array}$ \\
\hline
\end{tabular}

\section{HASIL DAN PEMBAHASAN}

Berdasarkan hasil penelitian, dilakukan uji normalitas data religusitas dan regulasi emosi. Ditemukan nilai signifikansi di bawah 0,05, maka dapat disimpulkan bahwa nilai residual berdistribusi tidak normal.

Untuk menguji hipotesis penelitian, peneliti melakukan uji korelasi antar variabel religiusitas dan regulasi emosi. Dari hasil uji korelasi, ditemukan terdapat hubungan yang signifikan antara variabel religiusitas dan regulasi emosi $(r=0,248, p<0,05)$.

Hasil koefisien korelasi menunjukkan angka yang bernilai positif atau berada pada poin 0,248. Oleh sebab itu, maka dapat disimpulkan bahwa walaupun keeratan hubungan tergolong lemah (nilai $\mathrm{r}$ di bawah 0,4), namun terbukti ada hubungan antara variabel religiusitas dan regulasi emosi. Hal ini berarti, semakin tinggi nilai variabel religiusitas, maka makin tinggi pula variabel regulasi emosi.

Hasil penelitian ini dapat dijelaskan dengan faktor intrinsik dan ekstrinsik dalam variabel religiusitas. Faktor intrinsik dapat mempengaruhi proses regulasi emosi setiap individu. Menurut Sharp (2010), faktor intrinsik seperti berdoa, dapat membantu individu dalam menafsirkan kembali setiap situasi emosional yang dihadapi oleh individu.

Demikian pula faktor ekstrinsik dalam variabel religiusitas, dapat membantu siswa untuk meregulasi emosinya. Menurut Diener et. al., (2011) dukungan sosial yang ada pada komunitas rohani atau religiusitas dapat membantu individu dalam mengurangi atau meregulasi emosi negatif. Siswa - siswi yang terlibat dalam penelitian ini merupakan siswa-siswi yang bersekolah di sekolah Kristen. Mereka melakukan berbagai kegiatan kerohanian secara rutin. Mereka terbiasa untuk berdoa bersama, mengikuti renungan pagi, dan mengikuti pembelajaran Agama Kristen. Sekolah pun memfasilitasi siswa untuk dapat mengikuti berbagai komunitas kerohanian seperti sekolah minggu dan bina iman siswa.

Kedua faktor, baik intrinsik dan ekstrinsik yang terjadi dalam proses religiusitas dapat membantu individu dalam meregulasi emosi mereka. Oleh sebab itu, perlu adanya dukungan yang tepat dari orang di sekitar untuk dapat memastikan proses religiusitas siswa berjalan dengan baik sehingga mereka dapat mampu untuk meregulasi emosi dengan lebih baik. 


\section{KESIMPULAN DAN SARAN}

Berdasarkan hasil penelitian, ditemukan bahwa terdapat hubungan antara variabel religiusitas dengan variabel regulasi emosi, walaupun keeratan hubungannya tergolong lemah. Makin tinggi religiusitas siswa, makin tinggi pula regulasi emosi mereka.

Terdapat beberapa saran yang dapat diberikan berdasarkan penelitian ini. Pertama, perlu dilaksanakan penelitian dengan sampel yang lebih luas. Hasil penelitian ini tidak dapat mewakili seluruh siswa sekolah dasar karena hanya dilakukan di satu sekolah dasar X. Kedua, sekolah perlu memfasilitasi siswa untuk dapat mempelajari karakter yang baik dan regulasi emosi sehingga dapat mengurangi konflik yang terjadi di sekolah.

\section{Ucapan Terima Kasih (Acknowledgement)}

Terima kasih kepada kepala sekolah SD X dan segenap jajaran guru atas izin yang diberikan kepada peneliti untuk dapat melakukan penelitian ini. Peneliti juga berterima kasih kepada pihak yang mengulas penelitian ini.

\section{REFERENSI}

Bekerman, Z., \& Zembylas, M. (2018). Emotion, emotional intelligence, and motivation: Psychologized language in education. New York, NY: Palgrave Macmillan.

Diener, E., Tay, L., \& Myers, D. G. (2011). The religion paradox: If religion makes people happy, why are so many dropping out?. Journal of Personality and Social Psychology, 101(6), 1278-1290. doi: 10.1037/a0024402

Etkin, A., Egner, T., \& Kalisch, R. (2011). Emotional processing in anterior cingulate and medial prefrontal cortex. Trends in Cognitive Sciences, 15(2), 85-93. doi:10.1016/j.tics.2010.11.004.

Ford, B. Q., \& Gross, J. J. (2018). Emotion regulation: Why beliefs matter. Canadian Psychology/Psychologie canadienne, 59(1), 1-14. https://doi.org/10.1037/cap0000142

Gross, J. J. (1998). The emerging field of emotion regulation: An integrative review. Review of General Psychology, 2(3), 271-299. doi:10.1037/1089-2680.2.3.271

Gross, J. J., \& John, O. P. (2003). Individual differences in two emotion regulation processes: Implications for affect, relationships, and well-being. Journal of Personality and Social Psychology, 85(2), 348-362. https://doi.org/10.1037/0022-3514.85.2.348

Gullone, E., \& Taffe, J. (2012). The emotion regulation questionnaire for children and adolescents (ERQ-CA): A psychometric evaluation. Psychological Assessment, 24(2), 409-417. doi:10.1037/a0025777

Hurlock, B. (2013). Perkembangan anak (edisi keenam). Jakarta: Erlangga.

Joseph, S., \& DiDuca, D. (2007). The dimensions of religiosity scale: 20-item self-report measure of religious preoccupation, guidance, conviction, and emotional involvement. Mental Health, Religion \& Culture, 10(6), 603-608.doi:10.1080/13674670601050295

Pennequin, V., Questel, F., Delaville, E., Delugre, M., \& Maintenant, C. (2019). Metacognition and emotional regulation in children from 8 to 12 years old. British Journal of Educational Psychology, 1-16. https://doi.org/10.1111/bjep.12305

Roseman, L., Demetriou, L., Wall, M. B., Nutt, D. J., \& Carhart-Harris, R. L. (2017). Increased amygdala responses to emotional faces after psilocybin for treatment resistantdepression. Neuropharmacology, 142, 263-269 doi:10.1016/j.neuropharm.2017.12.041

Sharp, S. (2010). How does prayer help manage emotions?. Social Psychology Quarterly, 73(4), 417-437. doi: 10.1177/0190272510389129 
Vishkin, A., BigMan, Y., \& Tamir, M. (2014). Religion, emotion regulation, and well-being. In C. Kim-Prieto (Ed.). Positive psychology of religion and spirituality across cultures, 9, 247-269. https://doi.org/10.1007/978-94-017-8950-9_13 